\title{
The biological disappearance rate of prothrombin, Factors VII, IX and X from plasma in hypothyroidism, hyperthyroidism, and during fever
}

Citation for published version (APA):

Loeliger, E. A., van der Esch, B., Mattern, M. J., \& Hemker, H. C. (1964). The biological disappearance rate of prothrombin, Factors VII, IX and X from plasma in hypothyroidism, hyperthyroidism, and during fever. Thrombosis et diathesis haemorrhagica, 10(2), 267-277. https://doi.org/10.1055/S-0038-1654782

Document status and date:

Published: 01/01/1964

DOI:

10.1055/S-0038-1654782

Document Version:

Other version

Please check the document version of this publication:

- A submitted manuscript is the version of the article upon submission and before peer-review. There can be important differences between the submitted version and the official published version of record.

People interested in the research are advised to contact the author for the final version of the publication, or visit the DOI to the publisher's website.

- The final author version and the galley proof are versions of the publication after peer review.

- The final published version features the final layout of the paper including the volume, issue and page numbers.

Link to publication

\footnotetext{
General rights rights.

- You may freely distribute the URL identifying the publication in the public portal. please follow below link for the End User Agreement:

www.umlib.nl/taverne-license

Take down policy

If you believe that this document breaches copyright please contact us at:

repository@maastrichtuniversity.nl

providing details and we will investigate your claim.
}

Copyright and moral rights for the publications made accessible in the public portal are retained by the authors and/or other copyright owners and it is a condition of accessing publications that users recognise and abide by the legal requirements associated with these

- Users may download and print one copy of any publication from the public portal for the purpose of private study or research.

- You may not further distribute the material or use it for any profit-making activity or commercial gain

If the publication is distributed under the terms of Article 25fa of the Dutch Copyright Act, indicated by the "Taverne" license above, 


\section{THROMBOSIS ET DIATHESIS HAEMORRHAGICA}

EDITORES: K. M. BRINKHOUS, CHAPEL HILL; F. BUCHNER, FREIBURG/BREISGAU; E. DEUTSCH, WIEN; J. E. JORPES, STOCKHOLM; F. KOLLER, BASEL; J. ROSKAM, LIEGE; J.-P. SOULIER, PARIS; I. S. WRIGHT, NEW YORK

The Biological Disappearance Rate of Prothrombin, Factors VII, IX and X from Plasma in Hypothyroidism, Hyperthyroidism, and

\section{During Fever}

From the Haematology Section of the Department of Internal Medicine (Head: Prof. J. Mulder, M.D.), University Hospital, and the Thrombosis Service (Head: E. A. Loeliger, M.D.,), Leyden, The Netberlands

E. A. Loeliger, B. vander Esch, Mieke J. Mattern and $\mathrm{H}$. C. $\mathrm{He} \mathrm{mker}$



F. K. SCHATTAUER-VERLAG - STUTTGART 
The disappearance rate of coagulation factors from plasma generally has been determined in normal individuals and in patients suffering from congenital coagulation factor deficiency, but otherwise being healthy. Little is known about the disappearance rate under altered metabolic conditions. During the last few years we have collected data concerning the biological half-life of Factors II, VII, IX and X in hypothyroidism, hyperthyroidism, and during fever. The results seem worth publishing.

\section{Patients}

Fifteen normal individuals (members of the staff, average age about 30 years), 10 patients with myxoedema*, 5 patients with thyreotoxicosis*, 5 patients with elevated body temperatures, and 6 "control" patients (patients without fever and with apparently normal thyroid function) are included in this study. Pertinent data concerning the patients are given in Table 1.

\section{Methods}

Both normal individuals and patients were given a loading dose of $80-100 \mathrm{mg}$ acenocoumarol (Sintrom "Geigy") between 9:00 p.m. and 2:00 a.m., followed by one daily dose of at least $40 \mathrm{mg}$ until the end of the experiment; this high amount of a 4-hydroxycoumarin derivative, approximately ten times the normal mean therapeutic dose, is considered to block synthesis of Factors II, VII, IX and X. At the end of the experiment, the effect of acenocoumarol was counteracted, if necessary, by an oral dose of 10 to $30 \mathrm{mg}$ vitamin $\mathrm{K}_{1}$ (Konakion "Roche"). In the "control" patients and in case of myxoedema, administration of the drug in a therapeutic dose was continued prophylactically.

* We are indebted to Prof. A. Querido, M.D., and his staff, Department of Endocrinology of the University Hospital, Leyden, for their invaluable cooperation.

Thrombos. Diathes. haemorrh. 


\begin{tabular}{|c|c|c|c|c|}
\hline ש & 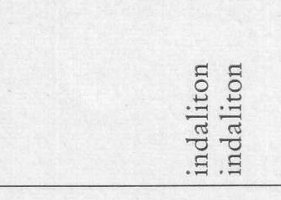 & 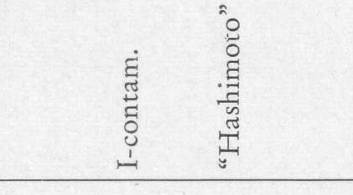 & 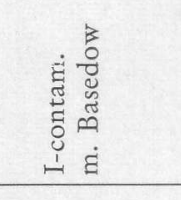 & 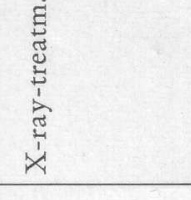 \\
\hline क्षे & \multicolumn{4}{|c|}{ 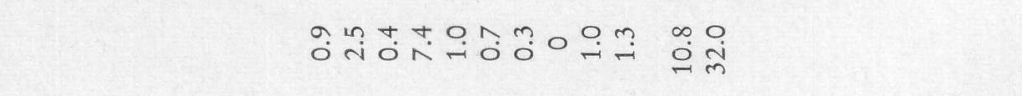 } \\
\hline $\begin{array}{l}0 \\
0\end{array}$ & & $\begin{array}{l}0000 \\
0+0 m=04-7 \\
m+m i n t a\end{array}$ & $\begin{array}{l}\infty \\
0 \\
0\end{array}$ & \\
\hline तi & &  & 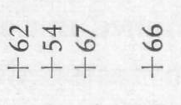 & \\
\hline 흘 & &  & పू్స & \\
\hline 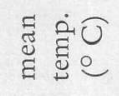 & 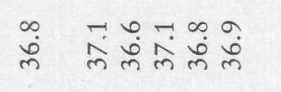 & 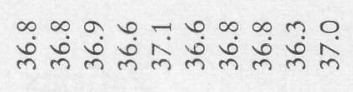 &  & \\
\hline 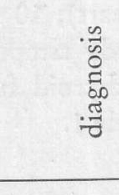 & 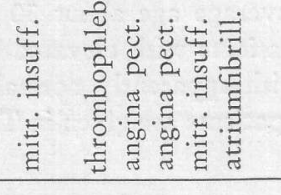 & 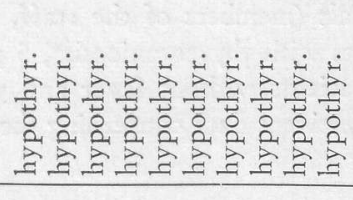 & 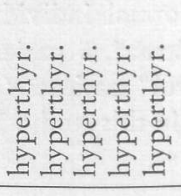 &  \\
\hline : & 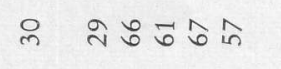 & 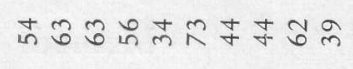 & 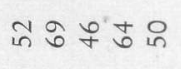 & 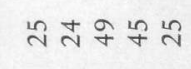 \\
\hline ڤ్ & $\omega \quad \Xi \Xi \approx \leftarrow+$ & 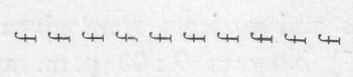 & $\Xi \equiv 4+4$ & 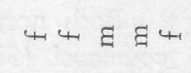 \\
\hline ह气 & 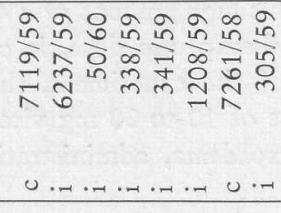 & 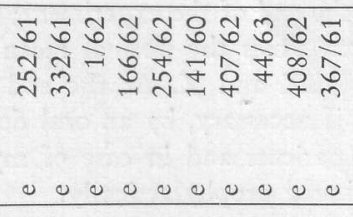 & 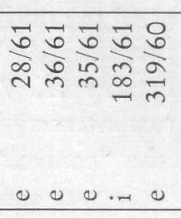 & 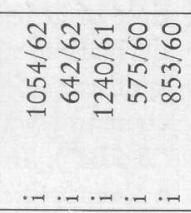 \\
\hline  & 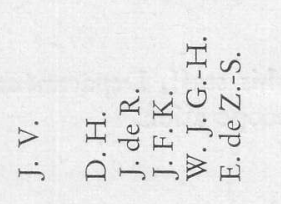 &  & 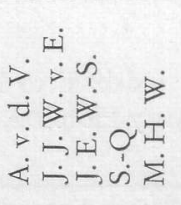 & 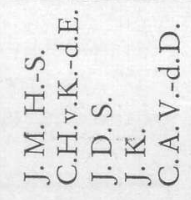 \\
\hline
\end{tabular}


Five $\mathrm{ml}$ blood samples were taken through a meticulous venepuncture using a polished stainless-steel needle directly into a plastic tube containing $0.1 \mathrm{ml}$ sodium citrate $0.55 \mathrm{~mol}$, at the intervals indicated in the Figures. The blood was centrifuged at 2300 r.p.m. for 30 minutes in order to obtain platelet-poor plasma. Plasma was handled and stored in carefully siliconized glassware.

Analysis of coagulation was usually carried out within two hours, and exceptionally as much as six hours after venepuncture. All coagulation tests were performed in ordinary glassware, preheated to $37^{\circ} \mathrm{C}$ in a waterbath. For the measurement of the "prothrombin" time we used the procedure described originally by Quick (10). Brain thromboplastin of human origin was prepared according to Owren (9) and stored in small portions at $-25^{\circ} \mathrm{C}$. The normal "prothrombin" time value was $15.1 \pm 0.7$ seconds.

The activity of Factors II, VII, IX, and X was determined by means of the one-stage procedure as described by us (6). The substrate plasma for the determination of Factors VII and IX was collected from patients with congenital coagulation factor deficiency, that for the determination of Factors II and $\mathrm{X}$ was artificially prepared. The large normal range found for Factors II and X in "control" patients (Fig. 2 and 4) is due to large differences in activity of the different batches of the substrate plasma used. In the Factor IX test, $\mathrm{BaSO}_{4}$-adsorbed oxalated plasma was added to the incubation mixture (6).

In the evaluation of the results of Factor IX disappearance rate statistical analysis was applied $*$.

\section{Results}

After oral intake of the coumarin drug acenocoumarin, some hours elapse before the activity of Factors II, VII, IX and X starts to decrease and prolongation of the "prothrombin" time commences. This "silent period", which normally lasts 4-8 hours, appears to be shorter in thyreotoxicosis and fever (shortest value 2.5 hours), whereas in myxoedema the beginning of the reaction may occur as late as 15 hours after oral intake. The individual data can be estimated from Figures $1-4$.

The prolongation of the coagulation times appears to take place exponentially (2); straight lines are obtained when the logarithm of the coagulation time is plotted against observation time (Fig. 1, 2, 3, and 4). The tangent of the angle between these lines and the $\mathrm{X}$-axis is the parameter for the prolongation rate. The tangent values for coagulation times ("prothrombin" time as well as coagulation time found in the specific coagulation factor assay system) found in normal individuals are taken as reference for changes in the disappearance rate of the coagulation factors in patients. The degree of change is assessed by calculating the ratio, patient's value: normal value.

* We are indebted to Dr. E. F. Drion, Head of the Statistics Department T. N. O., The Hague, for his invaluable help with the statistical analysis. 

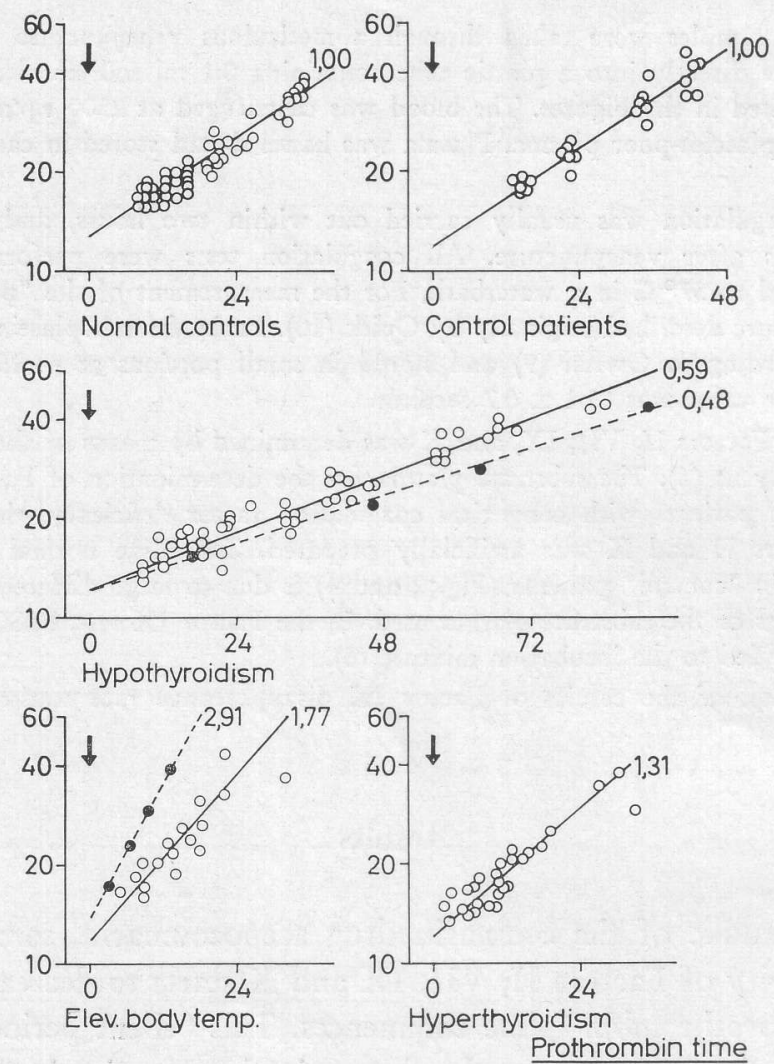

Fig. 1: Prolongation rate of the "prothrombin" time after blocking synthesis of Factors II, VII, IX and $\mathrm{X}$ in normal controls, "control" patients, and patients with different clinical conditions.

Abscissa: observation time (hrs.); ordinate: "prothrombin" time (sec.), logarithmic scale

Figure 1 demonstrates the prolongation rate of the "prothrombin" time. In thyreotoxicosis and patients with fever the rate is clearly increased, whereas in myxoedema it is decreased. The average acceleration in thyreotoxicosis and fever is 1.31 and 1.77 times normal, respectively; average doubling of the "prothrombin" time takes place after 18 and 13.5 hours, respectively, instead of the normal 24 hours. The highest rate is found in a case of sarcoma (i 1054/62) with remittent temperatures of up to $40^{\circ} \mathrm{C}$; it appears to be about three times normal (Fig. 1, dotted line). In myxoedema the increase of the "prothrombin" time is retarded on the average to 0.59 ; doubling of the "prothrombin" time takes place only after about 41 hours, on the average, instead of the normal 24 hours. The longest time required for doubling is 50 hours, which corresponds with a decrease of the prolongation rate to 0.48 times the normal value. 

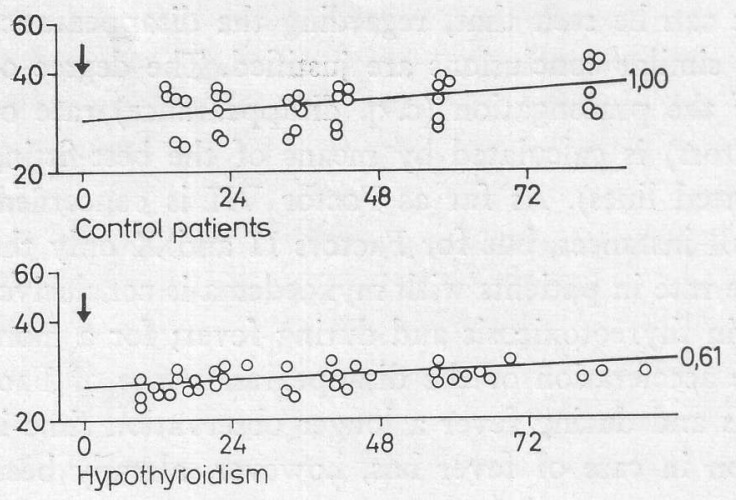

Fig. 2: Prolongation rate of the coagulation times found in the Factor II-assay system after blocking synthesis of Factors II, VII, IX and $\mathrm{X}$ in "control" patients and patients with different clinical conditions

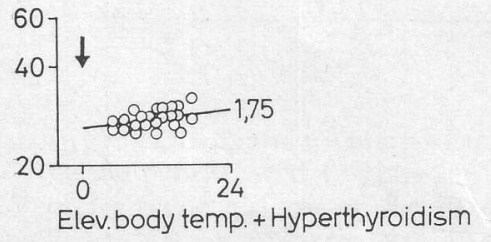

Abscissa: observation time (hrs.); ordinate: coagulation time (sec.), logarithmic scale

\section{Factor II}
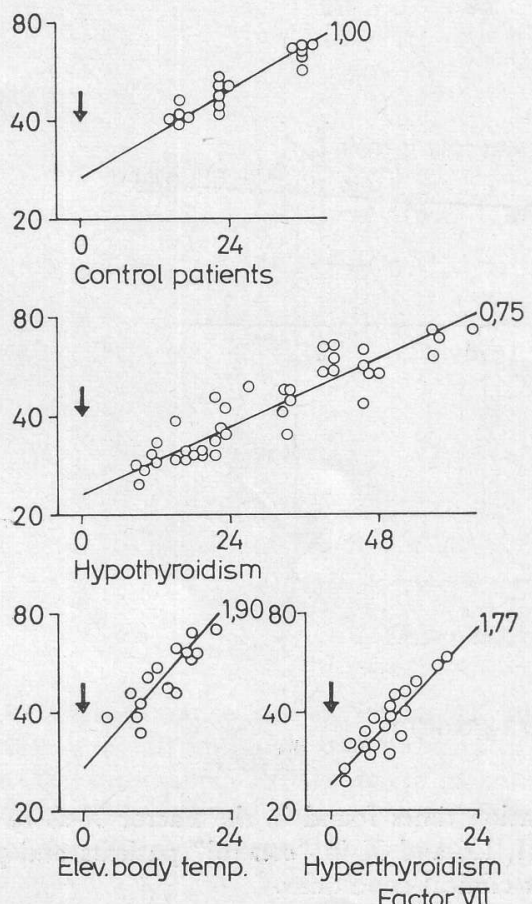

Fig. 3: Prolongation rate of the coagulation times found in the Factor VII-assay system after blocking synthesis of Factors II, VII, IX and X in "control" patients and patients with different clinical conditions.

Abscissa: observation time (hrs.); ordinate: coagulation time (sec.), logarithmic scale

Factor DII 
From Figures 2, 3 and 4 it can be seen that, regarding the disappearance rate of Factors II, VII and X, similar conclusions are justified. The degree of acceleration and retardation of the prolongation (c. q. disappearance) rate of the coagulation times (c. q. factors) is calculated by means of the best-fitting regression curves (solid and dotted lines). As far as Factor VII is concerned, the conclusions are evident in all instances, but for Factors II and X only the retardation of the disappearance rate in patients with myxoedema is conclusive; an acceleration seems probable in thyreotoxicosis and during fever; for a more significant result concerning the acceleration of the disappearance rate of Factors II and $\mathrm{X}$ in thyreotoxicosis and during fever a longer observation time is needed; a significant acceleration in case of fever has, however, already been demonstrated by one of us (2).
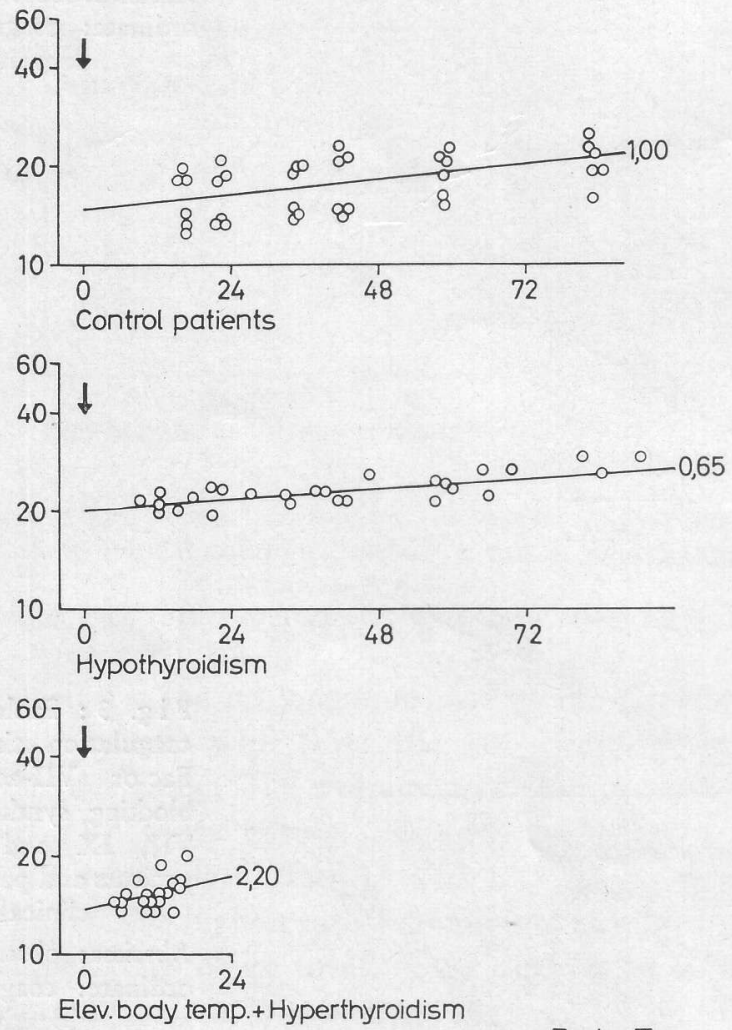

Factor X

Fig. 4 : Prolongation rate of the coagulation times found in the Factor $\mathrm{X}$-assay system after blocking synthesis of Factors II, VII, IX and X in "control" patients and patients with different clinical conditions.

Abscissa: observation time (hrs.); ordinate: coagulation time (sec.), logarithmic scale 


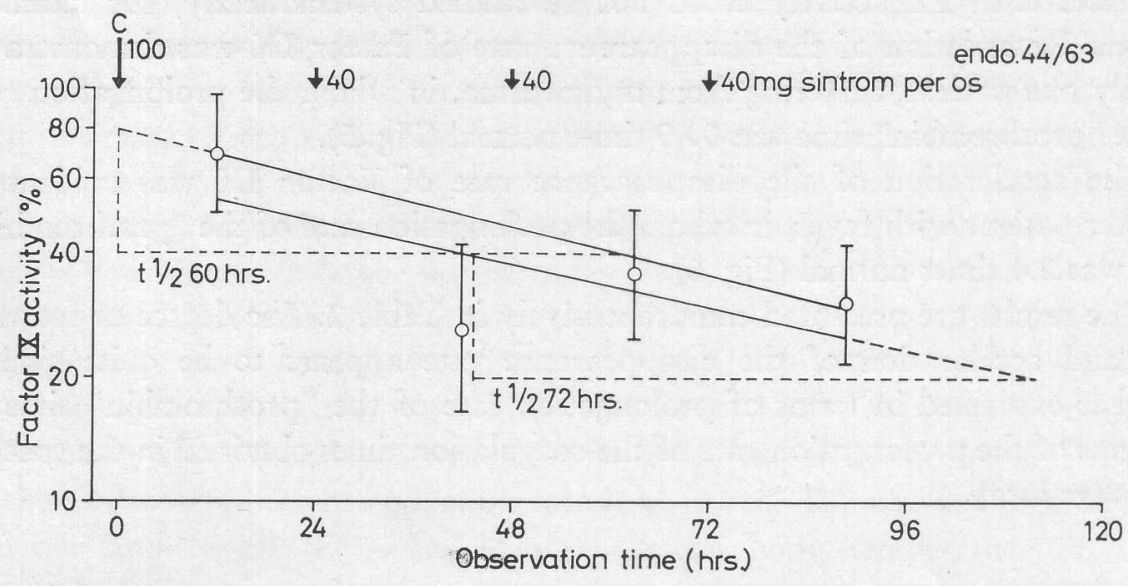

Fig. 5: Disappearance rate of Factor IX in terms of biological half-time in a hypothyroid female patient, aged 44 years (nr. e 44/63). The half-time values were obtained by means of regression analysis of the Factor IX-activities, found on four successive-days. Sixty hours (with a $95 \%$ confidence interval of $48-72$ hours) is the result obtained when the low Factor IX-activity, found on the second day, is not taken into account; 72 hours is the result when no value is omitted

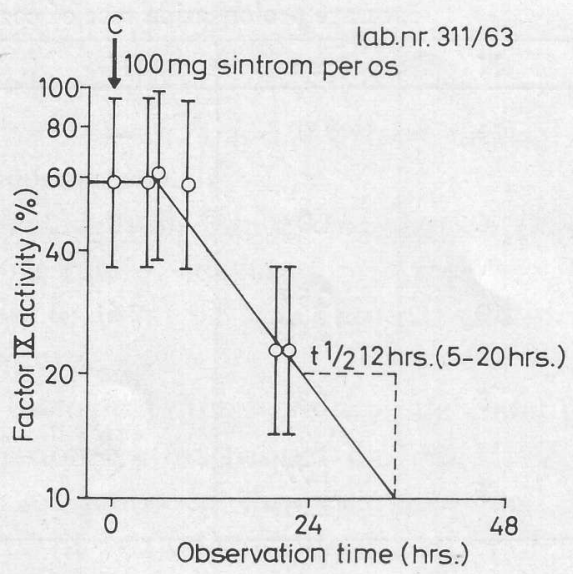

Fig. 6: Disappearance rate of Factor IX in terms of biological half-time (plus $95 \%$ confidence interval) in a male patient, aged 33 years, with continuously strongly elevated body temperature (about $39^{\circ} \mathrm{C}$ ), due to an untreated sarcoma (lab. nr. 311/63). The figures are the result of statistical analysis of the Factor IX-activity, found at the beginning and at the end of the experiment. The decrease of the Factor IX-activity was assumed to have started between 2.5 and 3 hours after oral intake of the loading dose acenocoumarin, together with the prolongation of the "prothrombin" time 
The Factor IX activity could not be studied systematically, for technical reasons. Retardation of the disappearance rate of Factor IX was demonstrated in only one patient, suffering from myxoedema, in whom the prolongation rate of the "prothrombin" time was 0.49 times normal (Fig. 5).

The acceleration of the disappearance rate of Factor IX was evident in another patient with fever, in whom the prolongation rate of the "prothrombin" time was 2.4 times normal (Fig. 6).

The results are presented comprehensively in Table 2 . The degree of retardation and acceleration of the disappearance rate appears to be quite similar whether expressed in terms of prolongation rate of the "prothrombin" time or in terms of the prolongation rate of the coagulation times obtained in the specific one-stage assay.

$\mathrm{T}$ a b 1 e 2 : Table 2 is a synopsis of the results obtained. The prolongation rate of the coagulation times found in patients is compared with those in normal controls and/or "control" patients. The results are presented as ratio, patient's prolongation rate: normal prolongation rate.

The figures given under "p. t." ("prothrombin" time), are more accurate than those under "II", "VII", and " $\mathrm{X}$ ", because the number of "prothrombin" times has been higher and also the error of determination is considerably lower for the "prothrombin" times than for coagulation times obtained from the assay of the three coagulation factors separately. The figures given under "II": "VII", and " $X$ " do not differ significantly from those given under "p. t."

\begin{tabular}{l|c|c|ccc}
\hline & \multicolumn{5}{|c}{ Average prolongation rate of coagulation times } \\
\cline { 2 - 5 } & $\mathrm{N}$ & p. t. & II & VII & X \\
\hline Normal controls & 15 & 1.0 & - & - & - \\
"Control" patients & 6 & 1.0 & 1.0 & 1.0 & 1.0 \\
Myxoedema & 10 & 0.59 & 0.61 & 0.75 & 0.65 \\
Thyreotoxicosis & 5 & 1.31 & & 1.77 & \\
Fever & 5 & 1.77 & 1.75 & & 2.2 \\
\hline
\end{tabular}

\section{Discussion}

Synthesis of prothrombin Factors VII, IX and X is supposed to be blocked almost completely after oral intake of a loading dose of $80-100 \mathrm{mg}(20-25$ tablets) followed by one daily dose of at least $40 \mathrm{mg}$ (10 tablets) of the 4-hy- 
droxycoumarin derivative acenocoumarol (Sintrom "Geigy"). Evidence for blocked synthesis during similar posology will be given elsewhere (2).

It takes about 2.5-15 hours before prolongation of the "prothrombin" time (c. q. decrease of the coagulation factor activity) begins; the shortest intervals ("silent period") between intake of the drug and reaction of the "prothrombin" time are found in fever and hyperthyroidism, the longest in myxoedema. Four to eight hours seems to be the normal range.

The prolongation rate of the "prothrombin" time is exponential up to values of about four times normal (2). The mean normal "doubling time" is 24 hours. In myxoedema the mean is much longer, about 41 hours, the longest "doubling time" being approximately 50 hours, whereas in hyperthyroidism and fever a marked increase of the prolongation rate is observed. The patients with thyreotoxicosis and fever (the latter having a mean body temperature of about $38.2^{\circ} \mathrm{C}$ ) show a mean acceleration of 1.31 and 1.77 times, respectively. The shortest "doubling time" was about 8 hours, which corresponds with a prolongation rate of about thrice normal; this concerned a patient with high body temperature due to a necrotizing malignant lymphoma. Since the longest "doubling time" in a case of myxoedema was about 50 hours, the fastest and slowest prolongation rate of the "prothrombin" time differ by a factor of at least 6 . It is most interesting in this respect that the shortest and longest "silent period" also differ by a factor of about 6 .

The prolongation rate of the Factor VII-coagulation time shows a clear-cut correspondence with the prolongation rate of the "prothrombin" time in all instances. The values for Factors II and X behave similarly, the correlation being most evident in myxoedema.

Considering the prolongation rate of coagulation times as parameter of the biological disappearance rate of coagulation factors, the latter appears to be far from constant; decrease to about 0.5 times normal and increase up to three times the normal rate can occur.

Alterations in the biological disappearance rate under pathological conditions occur in other coagulation factors besides Factors II, VII, and X. Concerning Factor IX we think an increased disappearance rate during fever has been proven by studies made during substitution therapy in haemophilia B (5) and is further demonstrated by the data in Fig. 6; a decrease of the Factor IX-disappearance rate was found in one of our myxoedema cases (Fig. 5). Factor VIII appears to be more rapidly consumed in patients after surgical treatment (8). The disappearance rate of fibrinogen was observed to be increased in a case of complete liver dystrophy accompanied by elevated body temperatures (4); on the other hand, significant retardation of consumption has been demonstrated in 
myxoedema (3). Serum albumin, in severe illness, appears to decay considerably faster than is normally the case (1). In fact, such changes seem to be a nonspecific phenomenon inherent in protein metabolism itself.

The cause of the alterations in metabolic activity of coagulation factors in myxoedema, thyreotoxicosis, and fever is as yet unknown. Thyroxin should be considered as one of the possible pathogenetic agents. Animal experiments may teach us more (7).

The practical consequences of large differences in the metabolic decay of the coagulation factors concerned in this study are at least twofold. Firstly, in coumarin treatment, therapeutic hypocoagulability will be reached in patients with high fevers up to three times earlier than in afebrile patients, whereas in hypothyroidism it will take much longer than is normally the case. This is of special importance in relation to combined heparin/coumarin treatment: heparin must be administered until the activity of Factors IX and X is between 10 and $25 \%$ of normal. Hence, in patients with normal metabolic activity, the minimal duration of heparin therapy will be $4-5$ days; hypothyroid patients must be treated for more than a week; with elevated body temperatures, however, 2 days of heparin will often be sufficient. Secondly, for substitution therapy in Christmas disease, the minimum amount of Factor IX needed for safe haemostasis, i. e. for the maintenance of a $25 \%$ level, will vary greatly with changes in the patient's metabolic activity. Up to three times the amount calculated from the normal disappearance rate of Factor IX will be needed. If the aetiology of the accelerated disappearance of coagulation factors were known, specific inhibitors could be used to drastically simplify substitution therapy in Christmas disease, and in other coagulation factor deficiencies.

\section{Summary}

The biological disappearance rate of coagulation factors II, VII, IX and X from plasma is decreased in myxoedema and increased in thyreotoxicosis. In patients with elevated body temperatures, an increase of up to three times the normal rate was observed. The clinical implications of these findings are briefly discussed.

\section{Résumé}

La vitesse de disparition des facteurs de coagulation II, VII, IX et X est diminuée en cas d'hypothyréoidie et accélérée en cas d'hyperthyréoidie. La vitesse peut être accélérée jusqu’à trois fois la normale chez des malades fiévreux. Les 
conséquences de ces résultats sont de grande importance dans le traitement aux anticoagulants et pendant la substitution chez l'hémophile par du plasma frais ou des préparations concentrées de facteurs de coagulation.

\section{Zusammenfassung}

Die biologische Halbwertszeit der Gerinnungsfaktoren II, VII, IX und X ist im Blut von Myxödempatienten vermindert und im Falle von Hyperthyreoidie erhöht. Bei fieberhaften Zuständen kann der dreifache Wert der Norm erreicht werden. Die Folgerungen dieser Befunde für die Klinik werden kurz diskutiert.

\section{References}

(1) Davies, J. W. L., C. R. R icketts and J. P. B u 11: Studies of plasma protein metabolism. Part I: Albumin in burned and injured patients. Clin. Sci. 23: 411 (1962).

(2) van der Esch, B.: Thesis, Leiden (1963).

(3) Hart, H. Ch.: Personal communication (1963).

(4) Hense n, A., and E. A. Loelige r : Antithrombin III, its metabolism and its function in blood coagulation. Thrombos. Diathes. haemorrh. (Stuttg.) 9: suppl. 1 (1963).

(5) L oeliger, E. A., and A. Hen se n : Substitution therapy in haemophilia B. Thrombos. Diathes. haemorrh. (Stuttg.) 6: 391 (1961).

(6) Loeliger, E. A., B. vander Esch, M. J. Mattern and A. S. A. den Bra$\mathrm{b}$ and er: Behaviour of factors II, VII, IX, and $\mathrm{X}$ during long-term treatment with coumarin. Thrombos. Diathes. haemorrh. (Stuttg.) 9: 74 (1963).

(7) Loelige r, E. A. et al.: In preparation.

(8) Nilsson, I. M., M. B lombäck and O. R a mgren : Haemophilia in Sweden. VI. Treatment of haemophilia A with the human antihaemophilic factor preparation (fraction I-0). Acta med. scand. 171: suppl. 379, 61 (1962).

(9) Owren, P. A., and K. A a s: The control of dicoumarol therapy and the quantitative determination of prothrombin and proconvertin. Scand. J. clin. Lab. Invest. 3: 169 (1951). (10) Quick, A. J.: The physiology and pathology of hemostasis. Henry Kimpton, London
(1951).

Received for publication 3.9. 1963

Der Verlag behält sich alle Rechte, besonders die des Nachdruckes, der Vervielfältigung und der Obersetzung, vor. 